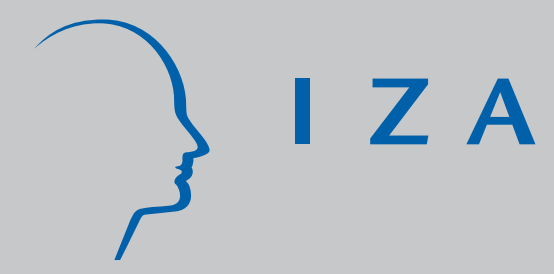

IZA DP No. 3974

Why Do Individuals Choose Self-Employment?

Christopher Dawson

Andrew Henley

Paul Latreille

J anuary 2009 


\title{
Why Do Individuals Choose Self-Employment?
}

\author{
Christopher Dawson \\ Swansea University \\ Andrew Henley \\ Swansea University \\ and IZA \\ Paul Latreille \\ Swansea University
}
Discussion Paper No. 3974
January 2009

IZA
P.O. Box 7240
53072 Bonn
Germany

\author{
Phone: +49-228-3894-0 \\ Fax: +49-228-3894-180 \\ E-mail: iza@iza.org
}

\begin{abstract}
Any opinions expressed here are those of the author(s) and not those of IZA. Research published in this series may include views on policy, but the institute itself takes no institutional policy positions.

The Institute for the Study of Labor (IZA) in Bonn is a local and virtual international research center and a place of communication between science, politics and business. IZA is an independent nonprofit organization supported by Deutsche Post Foundation. The center is associated with the University of Bonn and offers a stimulating research environment through its international network, workshops and conferences, data service, project support, research visits and doctoral program. IZA engages in (i) original and internationally competitive research in all fields of labor economics, (ii) development of policy concepts, and (iii) dissemination of research results and concepts to the interested public.
\end{abstract}

IZA Discussion Papers often represent preliminary work and are circulated to encourage discussion. Citation of such a paper should account for its provisional character. A revised version may be available directly from the author. 
IZA Discussion Paper No. 3974

January 2009

\section{ABSTRACT}

\section{Why Do Individuals Choose Self-Employment?*}

This paper undertakes an analysis of the motivating factors cited by the self-employed in the UK as reasons for choosing self-employment. Very limited previous research has addressed the question of why individuals report that they have chosen self-employment. Two questions are addressed using large scale labour force survey data for the UK. The first concerns the extent to which the self-employed are self-employed out of necessity, opportunity, lifestyle decision or occupational choice. The second concerns the extent to which there is heterogeneity amongst the self-employed on the basis of the motivations that they report for choosing self-employment. Factor analysis reveals a number of different dimensions of entrepreneurship on the basis of stated motivation, but with no evidence that being 'forced' into entrepreneurship through economic necessity is a significant factor. Motivation towards entrepreneurship is therefore highly multidimensional. Multivariate regression analysis is employed using a method to control for self-selection into self-employment. This reveals significant differences between men and women, with women concerned more with lifestyle factors and less with financial gain. Market-directed 'opportunity' entrepreneurship is more strongly associated with higher educational attainment. Those joining family businesses appear not to value prior educational attainment. Public policy to promote entrepreneurship therefore needs to be tailored carefully to different groups.

JEL Classification: L26, J24

Keywords: self-employment, entrepreneurship, motivation, occupational choice

Corresponding author:

Andrew Henley

School of Business and Economics

Swansea University

Singleton Park

Swansea, SA2 8PP

United Kingdom

E-mail: a.g.henley@swansea.ac.uk

*Dawson's contribution to this work was funded through a research studentship from the UK Economic and Social Research Council in association with the Welsh Assembly Government. 


\section{Introduction}

Self-employment is a form of labour market status which may encompass a wide range of different activity. Individuals may choose to be self-employed for many different reasons, and as a result the self-employed as a group may be highly heterogeneous. At one end of a possible spectrum the self-employed may be identified as entrepreneurial, single employee micro-businesses. A substantial body of research investigates the self-employed as entrepreneurs, using self-employment as an observable category which, albeit imperfectly, identifies the stock of entrepreneurial talent in the economy. At the other end this spectrum, self-employment may comprise a far less desirable state chosen reluctantly by individuals unable to find appropriate paid employment under current labour market conditions. So, for example, individuals wanting flexible working hours might choose self-employment if a paid employment contract offering sufficient flexibility is unavailable. For some self-employment may be chosen as the only available alternative to unemployment. Indeed in many developing economies self-employment may be viewed as a form of informal sector employment activity.

To gain an understanding of the 'positive' reasons why individuals might choose to become self-employed in order to venture a new business, a range of underlying motivations might be considered. These might include, for example, the need for self-expression, for independence, for status, or for pecuniary advantage. An extensive literature has addressed the process of the formation of entrepreneurial intention (Krueger et al., 2000). Empirical analysis typically develops a range of constructs related to the formation of entrepreneurial intention by using detailed questionnaires with samples of individuals and correlating these with reported strength of feeling about self-employment or entrepreneurship. In such studies 
reported levels of interest in entrepreneurship are often very high, particularly if questions are framed loosely in terms of open-ended career aspirations (see Blanchflower et al, 2001). Such high levels are difficult to square with much lower levels of actual self-employment in many countries. This suggests that intentions to become self-employed are either frustrated or that self-reported aspirations are vague and poorly formed. A further literature in economics models the choice of self-employment as an occupational choice decision, focusing on the importance of background and demographic associations. A key objective of this literature, taking its lead from the seminal study of Rees and Shah (1986), is to address whether the choice of self-employment might be motivated by the expected income differential between self-employment and employment for a given individual (see Le, 1999 and Parker, 2004, for surveys).

Very little, if any, research has addressed the question of why those who have actually chosen self-employment, made that choice. The preceding discussion suggested that the selfemployed can be classified into two broad types; those that have entered voluntarily for reasons such as independence, job satisfaction and or anticipated higher incomes, and those that have been 'pushed' into self-employed because of the absence of any other attractive alternative. If the motivations behind the decision to become self-employed are largely the former then self-employment can be viewed positively, providing the opportunity for individuals to improve their quality of life and/or for exploring creative entrepreneurial opportunities. Public policy which supports transitions into self-employment may therefore have wider economic and societal benefits. On the other hand, if a substantial number are in self-employment for 'negative’ reasons then approaches to public policy which frame selfemployment in entrepreneurial terms may unwittingly encourage some to launch business ventures for which they are ill-prepared and poorly resourced. Resulting spells of self- 
employment may be short and disheartening, and in some cases may simply result in delayed transition into unemployment.

In this paper we undertake an analysis of the motivating factors cited by the selfemployed in the UK as reasons for choosing self-employment over the alternative of paid employment working for someone else. This is undertaken by analyzing information contained within selected years of the UK Labour Force Survey, the main quarterly British household survey of labour market activity. The principal contribution of the paper is to provide a multivariate analysis of the association of a range of demographic and background characteristics with differing motivations for choosing self-employment, whilst controlling for the selection bias that arises because the self-employed as a group are unlikely to be representative of the whole population of the economically active. Specifically then we are concerned with two questions. The first concerns the extent to which the self-employed are self-employed out of necessity, opportunity, lifestyle decision or occupational choice. The second concerns the extent to which there is heterogeneity amongst the self-employed on the basis of the motivations that they report for choosing self-employment. A factor analysis finds the existence of a number of different dimensions of entrepreneurship on the basis of stated motivation. We conclude that there are significant differences between different types within the self-employed in terms of gender, ethnicity, educational attainment and housing tenure status. The remainder of the paper is structured as follows. Section 2 provides further background and reviews previous related literatures. Section 3 describes the data source used. Section 4 discusses the methodology chosen to model self-employment motivation. Section 5 describes the results of the analysis. Section 6 provides a concluding discussion. 


\section{Background and Previous Literature}

Entrepreneurship, as a topic for research, has grown dramatically in recent years primarily due to the relationship thought to exist between entrepreneurial activity and economic development. New firms are thought to create new employment opportunities (Parker and Johnson 1996, Ashcroft and Love 1996). New firms are also thought to be involved significantly in innovative activity, such that the role of innovative entrepreneurship is viewed as a key transmission mechanism between the creation of knowledge and economic growth (Audretsch, 2007). In addition, self-employment is an important occupational option for many in the labour force. At any one time it may account for approximately a tenth of all employed workers (Evans and Leighton, 1989). ${ }^{1}$ The perceived economic importance of entrepreneurial activity has thus spawned extensive research attempting to understand the characteristics of potential entrepreneurs, and the process of transition into entrepreneurship.

Whilst much previous empirical work has sought to determine what personal characteristics separate the self-employed from the employed, less attention has been given to the reasons that individuals cite for choosing self-employment. Moreover, very few previous studies employ nationally representative data, and those that do, have generally refrained from the further analysis of background characteristics that may be associated with these motivations. Previous research on entrepreneurial motivations has predominantly focused on 'push' versus 'pull' factors, or to a lesser extent the divergence between the necessity entrepreneur and the opportunity entrepreneur. Opportunity entrepreneurs start their business venture voluntarily, that is as individuals attracted into self-employment by perceived benefits such as independence, wealth, satisfaction, and personal and family motivations. In 
contrast, necessity entrepreneurs are 'pushed' into self-employment because of negative external forces, such as layoff and a subsequent lack of available paid-employment work.

At the aggregate level research has addressed the case for both 'push' and 'pull' theories by examining the relationship between self-employment and unemployment. There is little agreement here. Theoretical arguments have been constructed in support of both a positive and a negative relationship between self-employment and unemployment. On one hand, the prosperity-pull hypothesis suggests that individuals are more likely to attempt to start a new firm under conditions of economic expansion, when incomes are growing and opportunities are strong for market specialisation. Accordingly, a higher new firm formation rate may be associated with lower local unemployment. High unemployment will inhibit the market demand for products of the self-employed, and expose those who are selfemployment to greater risk of falling incomes and possibly bankruptcy. This implies a negative relationship between self-employment and unemployment.

On the other hand, according to the 'push' hypothesis, increasing levels of unemployment reduce the prospects for finding paid employment; as a result the expected returns from entrepreneurship become more attractive, pushing people into self-employment (Storey, 1982; Storey and Johnson, 1987). Moreover, second hand capital becomes both cheaper and more readily obtainable, as business closures increase in a time of recession. Thus the recession-push hypothesis suggests that worsening economic conditions activate previously dormant entrepreneurial ambitions, pushing individuals towards self-employment. Therefore, the principal issue when using unemployment as an explanatory variable in an empirical analysis of self-employment is one of identification. Unemployment will capture both supply side and demand side effects. Whilst most cross sectional analysis has found a negative association (for example, Evans and Leighton, 1989 and Blanchflower and Meyer, 
1994), the majority of times series studies report significant positive correlation between selfemployment and unemployment, reflecting the recession push hypothesis (for example Hamilton 1989). Some time series analyses, notably Black et al. (1996), Cowling and Mitchell (1997) and Robson (1998) also report a positive association between house prices and self-employment, consistent with a prosperity-pull hypothesis. Henley (2004), using individual-level longitudinal data, finds that initial housing wealth exerts a positive effect on the likelihood of being self-employed, but also reports that inertia plays an important role. Once someone has been pulled or pushed in to self-employment they more likely to continue to choose self-employment as an occupation. Some authors have identified windfall financial gains as positively associated with transition into self-employment, for example Georgellis et al. (2005). The transmission mechanism here between such indicators of individual economic prosperity and entrepreneurship is thought to be the relationship between the value of personal collateral and access to business loan finance.

Nearly all cross-sectional studies, using individual-level data, suggest that motivations for choosing self-employment are dominated by positive factors. However studies which sample only the self-employed suffer from a potential selection bias, which may lead to differences between stated (ex-post) motivation and actual (ex ante) motivations. That is, people may be reluctant to admit to negative factors ex post, preferring to provide information which is consistent with revealed behaviour. This potential caveat must be considered. Dennis (1996), reporting findings from a survey of around 3000 new business founders in the USA in the late 1980s, suggests that people enter into self-employment because they want to and not because of lack of available alternatives. In particular, just 8 per cent of the sample described 'the lack of alternatives' as a very important motivation for choosing self-employment. 57 per cent reported that using their 'skills and abilities' was a 
very important motivating factor. 54 per cent reported that both 'greater control over their life' and 'building something for the family' were very important motivating factors for forming their own business. In a very small-scale study, Hughes (2003) uses data from 61 Canadian female respondents in the province of Alberta who are self-employed. In general 'push' factors were not found to be the primary motivator behind the decision to become selfemployed. In contrast most were motivated by reasons such as independence and a positive working environment.

Similarly, using data from a much larger nationally representative survey of 3,840 self-employed Canadians for 2000, the same author reports that 'independence/freedom' is the most important motivator for both men and women when entering into self-employment (Hughes, 2006). 42 per cent of men and 24 per cent of women cite this as their main motivation. For women, 'work-family balance' and 'flexibility of hours' were the next most cited reasons. For men 'challenge' and 'prospects of more money' were the next most cited motivators. Overall Hughes suggests that over 71 per cent of men can be classified as 'opportunity' entrepreneurs, with only 22 per cent pushed into self-employment as a result of the lack of other suitable opportunities. A further 7 per cent of men could be classified as 'work-family entrepreneurs'. For women the percentages were 53 per cent, 22 per cent and 25 per cent respectively, demonstrating for women the far greater importance of work-family relationships when making the decision to become self-employed.

Taylor (1996), using UK data from 1991 found that self-employed Britons were less likely then those in paid-employment to regard pay and security as important job criteria, but were more likely to cite enjoyment and work satisfaction then their paid-employment counterparts. Smeaton (2003), using UK data from 1986 and 2000, found that in 198616 per 
cent of men cited 'unemployment/redundancy' as a motivating factor behind choosing selfemployment, whereas by 2000 this figure had risen to 26 per cent. For women the results were 5 and 10 per cent respectively. The most cited reason for men in both 1986 and 2000, at 39 per cent, was a preference for being one’s own boss. For women in 1986 the most cited motivating factor was 'going into business with a family member'. By 2000 women cited 'going into business with a family member' equally at 23 per cent with 'prefer to be own boss' and 'to follow an interest' as the most popular reasons. These results suggest that for both men and women, despite lower rates of UK unemployment in 2000, the self-employed seemed to have become more pessimistic about the availability of paid employment. Carter et al (2003), find evidence from US data that the motivations offered by nascent entrepreneurs when starting a business are dominated by self-realisation, financial success, innovation and independence.

Frey and Benz (2003) assess the level of job satisfaction of the self-employed compared to those in organizational employment using individual-level longitudinal data for Germany, Switzerland and the UK. Although these data sources are not specifically concerned with explicit motivations for choosing self-employment, the authors are able to conclude that higher levels of subsequently reported job satisfaction amongst those transitioning into self-employment are associated with an absence of hierarchy and sense of independence, as proxied by the size of the former employer.

Whilst the ease with which alternative employment can be obtained may be an important factor affecting a decision to transition into or remain in self-employment, opportunity cost considerations are also important; that is the wage rate that might otherwise be earned in paid-employment. In a seminal study, Rees and Shah (1986) find evidence that 
provides support for self-employment/paid-employment decisions being made rationally on the basis of a consideration of the expected earnings differential in the two states. Taylor (1996) also finds that individuals appear to be attracted to self-employment because of higher expected earnings. Similarly, Clark and Drinkwater (2000) suggest that the difference between an individual's predicted earnings in paid and self-employment exerts a powerful influence upon the employment decision. On the other hand other studies, including Gill (1988) and Earle and Sakova (2000), question this finding. These mixed empirical results may be explained by the divergence of data sources used, the robustness of model specifications and identifying exclusions, the ambiguous nature of the definition of employment or self-employment and the difficulties in accurately measuring selfemployment income and therefore the differential between the two states. It is therefore open to debate as to whether the expected financial gain from choosing self-employment is a predominant factor in determining occupational status, or whether other non-pecuniary considerations are of equal or greater importance.

Whilst this literature offers some pointers to potential motivations behind selfemployment as occupational choice, the direct survey evidence which is available is limited and usually based upon small samples under non-random selection criteria. Moreover, whilst an expansive literature exists on which personal characteristics separate entrepreneurs from non-entrepreneurs, little attempt has been made to determine systematically what personal characteristics are associated with the pattern of reported motivations for choosing selfemployment. $^{2}$ 


\section{UK Labour Force Survey Data Source}

The data used in the present study is obtained from the United Kingdom Quarterly Labour Force Survey (QLFS), covering the years 1999-2001. The QLFS is a national UK household survey in which all adults at each sampled postal address are asked about current labour market status and activity. The survey is used by the British government to provide important labour market intelligence data, but is also made available, after a certain time lag, to the research community in anonymised form for other secondary analysis. Although, the QLFS has a panel design, with each household of the sample interviewed for 5 consecutive quarters, we are primarily interested in individual responses to a schedule of 'recall' questions about self-employment choice asked of each individual, and so include only one observation on each individual for analysis. ${ }^{3}$ Interviews were achieved at approximately 59,000 addresses in each quarter, resulting in a sample of approximately 138,000 individual adult respondents in each quarter. The very large size of the QLFS means that it is possible to obtain a large sample of observations on the self-employed, facilitating robust analysis of particular sub-groups. The QLFS questionnaire includes schedules of household and individual questions covering family structure, housing information, economic activity, employment, educational and health issues.

Between 1999 and 2001, in each spring quarter only, all economically active adults, who reported that their current status was self-employed, were asked about their motives behind the decision to become self-employed. The exact wording of the question was as follows:

“(Question 108) May I just check, why did you become self-employed? Was it... 1. to be independent / a change 
2. wanted more money

3. for better conditions of work

4. family commitments / wanted to work at home

5. opportunity arose - capital, space, equipment available

6. saw the demand / market

7. joined the family business

8. nature of the occupation

9. no jobs available (locally)

10. made redundant

11. other reasons

12. no reason given”

(Source: QLFS questionnaire, Spring Quarter (March to May) 1999)

Each individual respondent was asked to choose up to four reasons. Individual observations are pooled across the three available Spring quarters providing a total pooled sample of 147,686 economically active individuals, of which 17,507 (11.9 per cent) are self-employed. ${ }^{4}$ As a result of multiple choices there are 23,851 choice responses to the question for these 17,507 self-employed respondents. Table 1 reports the proportions of the self-employed who provide each reason for becoming self-employed using the pooled data over the period 1999 to 2001. Table 2 reports the proportions of total responses for each reason given, providing columns which sum to 100 percent.

Overall Tables 1 and 2 suggest that, for the majority of respondents, entry into selfemployment is influenced by a range of non-pecuniary factors, of which the need for 'independence' is the most pronounced. This finding supports the conclusions in Dennis (1996) and in Frey and Benz (2004) who suggest the attraction of entrepreneurship is work satisfaction and independence, irrespective of income and hours worked. The next most cited motivation in the QLFS is the 'nature of the occupation'. This result suggests that a significant minority of the self-employed select themselves into an occupation, such as a professional trade in the construction sector or a profession such as lawyer or accountant, in which self-employment is the most common mode of employment. 
Other motivations, reflecting 'pull’ factors, attract significant response levels. 5.4 per cent of respondents cite the desire for 'better working conditions' and 8.8 per cent indicate as a motivation that they 'saw the demand' for the product or service which they felt they had to potential to provide. The least cited reason for choosing self-employment is the negative motivation of a lack of 'availability of jobs locally'. The nature of this option directly focuses attention on those respondents who were forced into self-employment as the only viable alternative to unemployment. Only just over 3 per cent of individuals indicate that the lack of jobs available locally was a motivation behind their transition into self-employment. This implies that for most the decision to become self-employed is overwhelmingly a positive action. However, whilst there appears to be a low proportion motivated by the 'availability of jobs locally' it is important to note that the UK unemployment rate averaged only around 6 per cent over the time period in question. The restrictive nature of this question makes it clear that those individuals who cite this reason have been pushed into selecting self-employment. Many of the other possible motivations, such as 'more money', 'joined the family business' and 'family commitment' could operate as either 'push' or 'pull' factors. For example, 'more money’ could be suggestive of attractive higher earnings in self-employment or could be suggestive of perceived poor wages in the paid-employment sector. Moreover, motivations that might typically be considered as attractors - for example, 'to be independent' and 'better conditions of work', can undoubtedly also operate as 'push' factors. That is, a lack of independence and poor working conditions in paid-employment pushes individuals into selfemployment. The difficulty of separating 'push' and 'pull' factors is emphasized further by the multiple response nature of the question. Specifically, individuals may highlight both 'push' and 'pull' factors operating simultaneously to influence their decision to become selfemployed. 
We turn now the different pattern of responses between men and women. Table 1 reports the results of t-tests for the significance of the difference in the response rates between men and women for each motivating reason. In all but two cases these differences are statistically significant. However 'independence' and 'nature of the occupation' are the two most commonly cited motivations for both men and women, although the proportion of women citing 'independence' is considerably lower than for men. The most important difference in the pattern of responses is that nearly 22 per cent of women cite 'family commitments' as a reason for choosing self-employment, compared to only 2 per cent of men. Corresponding to the importance of balancing family and work for women, it is also clear that women are less likely to cite financial gain as a reason for choosing selfemployment. Self-employment for women is far more likely to be framed in broader quality of life terms, than in terms of narrow pecuniary advantage.

As an exercise in attempting to identify key dimensions in the pattern of reasons given for choosing self-employment, Table 3 reports the results of a factor analysis. Since it is clear that key demographic factors may be correlated with the pattern of responses, the factor analysis includes gender and age as well as the different reasons for choosing selfemployment. The method of estimation is maximum likelihood and the preferred number of factors which results is seven. Table 3 reports the eigenvalues of each factor in the first row and factor loadings for each variable (age, female and eleven different reasons for choosing self-employment ${ }^{5}$ ). Factor loadings above (absolute) thresholds of 0.1 and 0.2 are highlighted. We suggest the following typology of different dimensions of entrepreneurship, corresponding to the different estimated factors and their factor loadings, in the order of eigenvalue as reported in the Table: 
1. idiosyncratic entrepreneurship; those choosing self-employment regardless of opportunity and fit with professional background for 'other reasons';

2. market-facing opportunity entrepreneurship; those choosing self-employment because of perceived external opportunity, but contrary to prior professional background;

3. professional entrepreneurship; those choosing self-employment to join professional partnerships and establish a professional practice;

4. family entrepreneurship; those choosing self-employment to join family businesses, some of which may be professional in nature;

5. independence-seeking entrepreneurship; those actively attracted to self-employment by a desire for independence, not associated with economic necessity;

6. lifestyle entrepreneurs; those, particularly women and younger people, who choose self-employment because it offers improved ability to balance work and family commitments, but not associated with economic necessity;

7. reward-seeking entrepreneurship; those younger people voluntarily leaving paid employment to pursue actively financial reward and improved working conditions.

This exercise in data description points to significant heterogeneity in the motivations behind particular individual decisions to choose self-employment. The majority of these dimensions entail considerable elements of 'pull'. In fact it is noticeable that 'push' factors tend to be absent. Indeed neither 'no jobs available' nor 'made redundant' attract positive loadings in any of the estimated factors. Conversely, the loadings for 'saw the demand/market' are also across all estimated factors low, suggesting that it is very unusual for someone to choose self-employment mainly because they have identified a market niche. Rather than focused on 'demand', opportunity entrepreneurship appears to be driven by 'supply' considerations related to the availability of resources. The significant dimensions of 
entrepreneurship appear to be related to the type of entrepreneurial activity (professional, family business), the need for independence and/or financial reward, and, particularly in the case of women, lifestyle considerations.

\section{Methodology}

The purpose of this section is to describe the empirical methodology used to model associations between a range of background and demographic factors and particular motivations for choosing self-employment. This is in order to understand more about which individuals are more likely to indicate particular motivations for self-employment. The approach adopted recognizes that the self-employed are a non-random sample of the economically active, and therefore that any modeling of the motivations of the self-employed must control for the non-random nature of the sample. This is undertaken using a selection bias correction method. Uncorrected estimates of the association between a certain background factor and one of the motivations will typically provide spurious indicators of the statistical significance of that association.

The conventional approach to this statistical issue has been to employ a Heckman selection correction (Heckman 1979). However identification in the Heckman model rests on establishing the validity of covariate exclusion restrictions. In short there must be at least one explanatory factor that influences sample selection but does not determine the outcome. Where the economic and social processes determining sample selection are very similar to those determining the outcome in question, such an exclusion restriction may not exist. In practice model identification may come down to finding ex post one or more covariates whose coefficients fail to attract statistical significance in the outcome equation and might on 
empirical grounds be restricted to zero. In the present case it seems unlikely that such restrictions might exist ex ante, since the underlying processes which determine whether someone is self-employed are likely to very similar to those which determine the reason why someone chose to be self-employed.

Sartori (2003) develops an estimator where selection and outcome equations can share a common structure and where identification is achieved on the assumption of identical errors in the selection and outcome equations. Equations (1) and (2) show selection and outcome processes under the case of non-random selection for individual $i$ from a sample 1 to $n$. The dependent variable in equation (1) represents sample selection on the basis of an underlying standardised continuous process. The dependent variable in the outcome equation (2) is also unobserved, standardised and continuous. The explanatory variables, $x$, are the same in both selection and outcome equation, with $\gamma$ and $\beta$ denoting the different coefficient vectors in each. Each equation contains a normally distributed, mean zero error term, $v_{1}$ and $v_{2}$.

$$
\begin{aligned}
& U_{1 i}=\gamma^{\prime} x_{i}+v_{1 i} \\
& U_{2 i}=\beta^{\prime} x_{i}+v_{2 i}
\end{aligned}
$$

Instead of observing the $U$ 's, we observe two dichotomous variables, $Z_{1 i}$ and $Z_{2 i}$, shown as the dependent variables in equations (3) and (4). The relationship between the unobserved selection and outcome processes and the observed dichotomous variables is as follows:

$$
\begin{aligned}
& Z_{1 i}=0 \text { if } U_{1 i}<0, Z_{1 i}=1 \text { if } U_{1 i} \geq 0 \\
& Z_{2 i}=0 \text { if } U_{2 i}<0, Z_{2 i}=1 \text { if } U_{2 i} \geq 0
\end{aligned}
$$

Under the key identifying assumption that the error terms in equations (3) and (4) are identical, that is $v_{1}=v_{2}$, Sartori then proceeds to derive a maximum likelihood estimator for the effect of the independent variables on the dependent outcome variable of interest, taking 
into account the selection process. This can be described by defining three random variables $Y_{i j}$ such that:

$$
\begin{aligned}
& Y_{0 i}=1 \text { if } Z_{1 i}=0 \text {, and } 0 \text { otherwise; } \\
& Y_{1 i}=1 \text { if } Z_{1 i}=1 \text { and } Z_{2 i}=0 \text {, and } 0 \text { otherwise; } \\
& Y_{2 i}=1 \text { if } Z_{1 i}=1 \text { and } Z_{2 i}=1 \text {, and } 0 \text { otherwise. }
\end{aligned}
$$

$Y_{0 i}$ has a value of 1 if the observation is not selected, $Y_{1 i}$ has a value of 1 if the observation is selected but the value of the outcome variable is 0 , and $Y_{2 i}$ has a value of 1 if the observation is selected and the value of the outcome variable is 1 . In order to construct a likelihood function for the model it is necessary to specify the data generating process for the probability that $Y_{j i}=1$ in each case. As shown by Sartori (2003) these probabilities are as follows:

$$
\begin{aligned}
& \operatorname{Pr}\left(Y_{0 i}=1\right)=\Phi\left(-\gamma^{\prime} x_{i}\right) \\
& \operatorname{Pr}\left(Y_{1 i}=1\right)=\left\{\begin{array}{l}
\Phi\left(-\beta^{\prime} x_{i}\right)-\Phi\left(-\gamma^{\prime} x_{i}\right) \text { if }\left(\gamma^{\prime}-\beta^{\prime}\right) x_{i}=0 \\
0 \text { otherwise }
\end{array}\right. \\
& \operatorname{Pr}\left(Y_{2 i}=1\right)=\left\{\begin{array}{l}
\Phi\left(\beta^{\prime} x_{i}\right) \text { if }\left(\gamma^{\prime}-\beta^{\prime}\right) x_{i}>0 \\
\Phi\left(\gamma^{\prime} x_{i}\right) \text { if }\left(\gamma^{\prime}-\beta^{\prime}\right) x_{i} \leq 0
\end{array}\right.
\end{aligned}
$$

$\Phi$ is the cumulative standard normal density function. The likelihood function is then conventionally defined as the product of the different probabilities, $P_{j i}$, for each combination for each individual:

$$
L^{*} \equiv \ln L=\sum_{i=1}^{n} \sum_{j=0}^{2} Y_{j i} \ln P_{j i}
$$

where $Y_{i j} \ln P_{i j}$ equals 0 if $Y_{i j}=0$ and $P_{i j} \leq 0$. 
The critical assumption here is that the error terms in the selection and outcome equations are identical. It is important to assess this model restriction. The assumption of (near) identical errors can be expected to hold when the decision processes behind selection and the outcome of interest are very similar, and result from the same causal process (see Sartori, 2003, p. 112). In the present case this seems reasonable, since, as already noted, the process governing the decision to be self-employed is likely to be very similar to that behind the motivation for that decision. Sartori also notes that the two processes should occur at the same time and/or in the same place, and in the present case this is by definition true.

For the purposes of the selection analysis an individual is defined as self-employed (i.e. $Z_{1 i}=1$ ) if they reported their employment status in their main occupation as selfemployment and gave at least one response to the question concerning their motive for choosing to become self-employed. The non-selected group are the paid-employed and are defined as those individuals reporting their employment status in their main occupation to be an employee.

The choice of which covariates to include as having potential association with different motivations for choosing self-employment is to some extent constrained by the nature of the QLFS data source. The QLFS is a deliberately designed as a large survey in order to allow the derivation of official estimates of labour market activity on a detailed spatial and occupational basis. However the trade-off here is that the questionnaire is kept fairly short, and therefore limited to largely factual questioning about household structure and housing circumstance, demographics, earnings and hours of work, educational attainment and health status. Little or no other attitudinal or cognitive background information is available. The previous discussion has highlighted the potentially crucial role of gender in moderating the formation of motivation towards self-employment and this is included as a key covariate, 
alongside other basic demographic information including age (in a non-linear quadratic form) and marital status. Membership of an ethnic minority is also included, since the relationship between ethnicity and entrepreneurial activity is one that has figured in previous literature. ${ }^{6}$ The potential role of household structure is captured through the inclusion of the number of dependent children under the age of 16 . Self-employed activities are higher heterogeneous and it is therefore important to control for the role of education in order to assess the extent to which both higher educated individuals may be motivated to choose self-employment as a route to professional status and less educated individuals may be motivated to choose selfemployment due to a lack of other economic alternatives. Educational attainment is captured in the model through a series of dichotomous highest level of educational attainment variables. These are: university or college degree level; other non-degree higher education; A-levels or equivalent (post-compulsory examinations taken at 18 as qualifying exams for college or university entrance), GCSE or O-levels (age 16 schooling attainment qualifications); and other qualifications. The literature on education and self-employment is mixed; arguments can be made for both a positive and a negative relationship. Skills associated with successful entrepreneurship may not necessarily be those skills obtained from formal qualifications. However, those with higher levels of education may select themselves into professional occupations where self-employment status, perhaps within the context of a professional partnership is more common. Housing tenure status is also included, not least because, as implied in the discussion above, owner-occupation status, either as a mortgagor or outright-owner, may provide access to business funding collateral. This may be associated with more positive motivations towards self-employment. A set of twelve regional dummy variables are included to capture any broad spatial patterns in self-employment which are not otherwise captured through variation in demographic and housing factors. Finally, as the data 
is pooled over three years, year dummy variables are included to capture any effect on stated motivations of changing aggregate economic or societal conditions.

\section{Empirical Results}

Table 4 reports estimated marginal effects from the regression of the selection equation. Only one equation is reported since the marginal effects of the selection equation remain identical for each different outcome, with only very minor variation in levels of significance. Levels of statistical significance are very high for most of the covariates. Older individuals are, other things equal, more likely to be self-employed, but the significance of the quadratic term suggests that the likelihood of self-employment increases at a declining rate. Women are, other things equal, four percentage points less likely to be self-employed, a result that is well-established in the literature. The disabled are 0.6 percentage points more likely to be self-employed, almost certainly reflecting the greater flexibility in working conditions that self-employment may offer. Members of ethnic minorities are nine percentage points more likely to be self-employed. The presence of dependent children raises the probability of self-employment. The precise explanation for this association is uncertain, but it may be related again to greater working flexibility. There is no statistically significant association between likelihood of self-employment and marital status. However the signs on the coefficients are plausible; negative for the married and positive for the widowed or divorced. Educational attainment is significantly related, other things equal, to the probability of self-employment. Those most likely to be self-employed have reached A-level qualifications but lack university or college qualifications. This is consistent with finding higher levels of self-employment amongst skilled individuals who have undertaken some post-compulsory schooling, but who preferred perhaps to pursue vocational rather than professional skills. Housing tenure status is also significantly associated with self- 
employment. All tenure groups are more likely, other things equal, to be in self-employment compared to those in social rental housing. Outright owners are, other things equal, over 4 percentage points more likely to be self-employed. This may reflect access to capital resources which can be used to provide collateral for business finance. Finally the year dummies show that the rate of self-employment falls very slightly in the later years.

Table 5 reports the estimated marginal effects for each outcome equation. Results will be discussed for each group of covariates in turn across the different motivations for choosing self-employment. Turning first to age, it is clear that the strongest positive association is with 'independence' - older individuals appear to be more likely to value independence as a positive attribute associated with entrepreneurship, and the results suggest a positive but decreasing association with age up to 56 years of age.. All other motivations are positively associated with age, but at a declining rate as indicated by negative quadratic terms; however the sizes of the associations are much smaller than for 'independence'.

There is a negative association between being female and the likelihood of stating a particular motivation for self-employment in all cases except for 'family / home'. These negative coefficients reflect lower levels of self-employment generally amongst women. However it is clear that women are significantly more likely than men to choose selfemployment in order to balance work and home commitments. The marginal effect here is over eight percentage points. There are some very large negative gender effects for other motivations. Women are 29 percentage points less likely to state 'independence' as a motivation. Additionally, 'more money' and 'nature of the occupation' are both approximately 15 percentage points less likely to be chosen by women compared to men, suggesting that female entrepreneurs are less interested in pecuniary rewards compared to 
their male counterparts and are less likely to choose occupations more commonly associated with self-employment.

Disability is in most cases positively associated with the different motivations for choosing self-employment, reflecting the positive association between self-employment status and being disabled. The strongest associations are for 'working conditions', 'occupation', 'no jobs' and in particular 'other reasons'. It may be the case that the disabled are more likely to be pushed rather than pulled towards self-employment, either because of segregation into particular occupations or because of discrimination in the paid employment market. To this extent it is noticeable that the more economic motivations such as 'money' have smaller coefficients, and that the only negative (albeit insignificant) coefficient is in the equation for 'opportunity arose'.

Membership of an ethnic minority is in most cases positively associated with the different reasons for choosing self-employment. Ethnic minorities are particularly likely, other things equal, to state 'independence' as a reason (marginal effect: nine percentage points). Other significant reasons are 'family business' and 'no jobs'. These findings are consistent with the view that members of ethnic minorities may choose self-employment because they are excluded from the formal labour market, and may prefer to build business ventures within their own communities, where formal skills, particularly host country language skills, are less necessary.

The presence of dependent children generally has a positive association with the different motivations. The role of children appears to be two-fold. On the one hand it raises the importance of financial motivations for self-employment - for example having a 
dependent child raises the likelihood of stating 'money' as a motivation by 2.6 percentage points. On the other hand having a dependent child also raises the attractiveness of selfemployment for those seeking independence (marginal effect of 4.2 percentage points per child) and flexibility to deal with family and home circumstances (marginal effect of 3.1 percentage points per child).

The marital status controls attract a mixed set of coefficients. Both those who are married (or cohabiting) and who were formerly married (widowed, divorced or separated) are more likely to report 'money' as a motivation compared to the never married. In either case however the motivations may be different. In the case of the formerly married, bereavement or separation may have resulted in financial distress and the need to increase income. For the married the motivation may be more aspirational - related to a stronger desire to 'build' a home compared to those not married. Thus the results show that, other things equal, those who are married are 2.4 percentage points more likely to cite 'family / home' as a motivation, reinforcing the association already noted above with dependent children The results show negative associations between being married and 'independence' (marginal effect of -3.3 percentage points) and 'occupation' (marginal effect of -2.5 percentage points). Being married may be associated with a stronger desire for financial security which is in turn associated with a greater tolerance for building a career working for an organization. Those formerly married are less likely, other things equal, to report 'family business' and 'occupation' as motivations for self-employment. This suggests that for these people entrepreneurship is pursued less as a long term career strategy and more for financial necessity. 
The results in Table 5 show a complex and varied association between educational attainment and different motivations for choosing self-employment. The better educated, in particular those individuals with degree-level qualifications, are more likely to report that self-employment was chosen for such reasons as 'independence', 'better working conditions' and the 'nature of their occupation'. In particular, the table shows significant positive marginal effects for university graduates compared to someone with no formal qualifications for 'independence' (3.2 percentage points), for 'working conditions' (1.5 percentage points) and for 'occupation' (7.4 percentage points). Degree holders are also very significantly more likely to cite 'other reasons' (6.2 percentage points). More educated individuals are also less likely to report 'family business', 'no jobs' or 'redundancy' as motivations. Graduates in particular are significantly more likely than others to report that self-employment was chosen because of the nature of their occupation, consistent with self-employment being a normal occupational status for sizeable numbers of university-educated professionals. It was noted in Table 4 that those whose highest academic qualification is A-levels (post-compulsory school examinations at age 18) are significantly more likely to be in self-employment. The pattern of coefficients in Table 5 for this group is rather different, with a number of significant positive associations with various motivations, especially 'independence' (marginal effect of 10.8 percentage points) and 'money' (marginal effect of 5.4 percentage point). In effect this group comprises individuals who have failed to achieve a standard of academic achievement for college or university entry, or have subsequently dropped out of higher education (although in the British context this seems less likely). They may be more independently minded, wellmotivated individuals who have chosen not to pursue higher education because of particular character traits associated with the desire to be successful as an entrepreneur outside of a usual organizational career path. 
Those individuals who have no formal qualifications are more likely to enter into selfemployment for reasons such as 'no jobs available locally', 'joined the family business' and 'more money' compared to most skill levels. These results are consistent with the unskilled being more likely to encounter greater problems in finding work, and less likely subsequently to command a high wage. Therefore individuals with no formal qualifications are significantly more likely to enter into self-employment due to the both the lack of jobs available locally and for pecuniary reasons, and therefore may ultimately find selfemployment to be a less fulfilling occupational choice. Similarly, those individuals who report 'family business' as a motivation are less likely to have acquired skills and more likely to have left education at an early stage in order to start working for that family business. Entry into self-employment may for such individuals have presented itself as a straightforward family expectation. Others with educational qualifications are significantly less likely to have entered self-employment because of a family business, with marginal probability effects ranging from around minus two percentage points for those with age 16 school qualifications to minus nine percentage points for higher education graduates.

As noted above home-ownership and private sector renter status are significantly positively associated with self-employment. Consistent with this finding in Table 4, Table 5 reveals a wide range of significant associations between home ownership and different motivations for choosing self-employment. For every motivation excluding 'no jobs available locally', there appears to be a strong association between home ownership (mortgaged and outright ownership) and the self-employment motivations. The same is also true for private sector renter status. In particular, individuals who own their houses outright are 24 percentage points more likely to be motivated by 'independence' than those renting social housing, 13 percentage points more likely to cite 'joined the family business' and 13 percentage points more likely to be motivated by 'nature of the occupation'. Perhaps the key issue here is to 
explain why those renting social housing are almost always less likely to report a particular motivation. Social housing status is associated with a wide range of other factors associated with poverty, such as low income, low skill and single parent status. These work additively to contribute to lack of economic opportunity. This self-employment seems much more likely to associated with 'forced' entrepreneurship. However, as the discussion above has highlighted, this type of self-employment appears to comprise only a small proportion of the total and does not figure as a significant dimension of entrepreneurship.

\section{Discussion and Conclusions}

The existing literature providing large scale survey evidence on why individuals choose self-employment is very limited. We currently know a good deal about who chooses self-employment, but not very much about why. This paper has analyzed data which is available over a particular time period between 1999 and 2001 within the UK Quarterly Labour Force Survey, a very large survey which asks a significant sample of the selfemployed to indicate up to four choices from a list of eleven possible reasons for their decision. Clearly some of these respondents will have been self-employed for some considerable length of time, while others may have only recently transitioned from another economic status. To that extent responses may be subject to some unknown element of recall bias, or ex post rationalization. Nevertheless such data is the best that is typically available. Longitudinal analysis, focusing on those recently transitioning into self-employment might be preferable, but such data, even where qualitative information on reasons for choice might be available, tends to yield much smaller samples.

This paper has established that the reported motivations for choosing self-employment are highly multi-dimensional, revealing very considerable heterogeneity within the self- 
employed as a group. In very broad terms the different motivational dimensions can be summarized as relating to the existence of opportunity to start of business, the nature of an individual's profession (if they have one), the desire for a particular lifestyle and need to balance family commitment with working life, and finally the opportunity afforded by having resources available to support a new business venture.

Significant differences in the pattern of response are apparent for certain groups. Women are much more likely to report lifestyle and family reasons for choosing selfemployment than men - a conclusion that is perhaps not surprising but does imply issues of equal opportunity. Women are less likely to report financial gain as a motivating factor. Two other groups for whom lifestyle issues figure more importantly are older individuals and members of ethnic minorities. However for the latter group, care must be taken in the interpretation of this finding, since we cannot rule out the possibility that it may be culturally more acceptable to provide a justification other than one which is financial for certain groups.

What we have termed opportunity entrepreneurship appears from the results to be associated with educational attainment. More educated individuals appear to be more likely to view self-employment in positive terms, offering independence and financial reward, as well as better working conditions. The least educated individuals, that is those lacking any formal academic qualifications, are the most likely to indicate that their choice of selfemployment arose from a lack of alternative employment opportunity. They are also most likely to indicate that the reason for choosing self-employment was in order to join a family business. This is a rather worrying finding, since it may indicate that for some individuals the incentive to acquire qualifications and skills is severely reduced, because they feel that there is an existing family business waiting for them. Such businesses may therefore perform 
poorly because of a lack of appreciation of the value of education and skills. This finding accords with other recent research on the relationship between management practice and firm performance (Van Reenen and Bloom, 2007). This research concludes that family-run businesses are significantly less likely to employ good management practices.

The present study has found little direct evidence for 'forced' entrepreneurship; that is significant numbers of individuals who appear to have chosen self-employment out of necessity because of loss of previous paid employment and a lack of other paid alternatives. The vast majority choose self-employment for positive reasons. However it should be noted that the time period covered by the data analyzed extends across the middle of a period of sustained economic growth in the UK economy. Whether this conclusion would be as robust during the current period of severe economic downturn and rapidly rising unemployment is open to debate and, with suitable data, further future analysis. Indeed it would give cause for considerable concern if the proportion choosing self-employment because it represents the only alternative to economic inactivity was to rise significantly in the next few years. Such 'forced’ choices may not lay solid foundations for well-resourced, successful new business ventures.

For public policy, the finding of significant heterogeneity amongst reasons for choosing self-employment suggests that policies to encourage successful entrepreneurship need to be tailored carefully to different groups, particularly demographic groups. For example so called ‘family-friendly’ policies may increase entrepreneurship amongst women. One feature of the results presented here is the rather limited number of individuals who report the perception of a market opportunity as a significant reason for choosing selfemployment. Given the significant numbers who report financial reward as a motivation, 
observers may be left pondering how many of these individuals actually achieve the significant improvement in earnings that they appear to desire. This in turn points to the need for policy interventions designed to promote more careful business planning amongst aspiring entrepreneurs. By contrast what might be termed supply-side factors appear to play a relatively larger role - 'opportunity’ entrepreneurs frame opportunity in terms of possessing sufficient resources to take advantage of a potential opportunity, rather than in terms of available market. Finally a small proportion of the self-employed chose this state because they joined a family business. Such individuals do not appear to be particularly well educated and may fail to appreciate the contribution that academic qualifications and other skills may make to business performance. Policy intervention needs to be designed carefully to target such individuals. 


\section{Footnotes:}

${ }^{1}$ Within the UK, self-employed individuals account for approximately $12.5 \%$ of the workforce. Blanchflower (2000) provides recent comparative data for OECD economies.

2 Previous literature has looked at the gender differences between motivations to become self-employed, and identified the importance of work-family balance issues for women. See Buttner and Moore (1997) and Hughes (2006) for an overview of the evidence.

${ }^{3}$ The choice of time period 1999 to 2001 is constrained by the availability of the question on motivation for becoming self-employed. This question has been asked only periodically in the QLFS and was dropped after 2001.

${ }^{4}$ Each member of the QLFS sample is interviewed for five consecutive quarters in order to provide a rotating longitudinal element to the survey. This means that the spring quarter files for 2000 and for 2001 included two observations on those who were self-employed in each year, and therefore a duplicate (although potentially inconsistent) response to the question on reasons for becoming self-employed. To avoid duplicate observations in our analysis, those individuals in the spring quarter 2000 sample who were also included in the spring quarter 1999 sample, and those in the spring quarter 2001 sample who were also included in the spring quarter 2000 sample, were deleted from the analysis. In principle one could have deleted the first rather than the second duplicate observation. Both methods were investigated, and it was found that the results of the secondary analysis in each case were almost identical.

5 "No reason given" is not included in the factor analysis.

${ }^{6}$ Parker (2004), Chapter 4 provides a comprehensive and succinct summary of arguments and evidence concerning this relationship. See Clark and Drinkwater (2000) for recent British evidence. 


\section{References}

Ashcroft, B.K. and Love, J.H. (1996), Firm births and employment change in British counties, Papers in Regional Science, 75(4): 1-18.

Audretsch, D.B. (2007), Entrepreneurship capital and economic growth, Oxford Review of Economic Policy, 23(1): 63-78.

Black, J., de Meza, D. and Jeffreys, D. (1996), House prices, the supply of collateral and the enterprise economy, Economic Journal, 106(434): 60-75.

Blanchflower, D.G. (2000), Self-employment in OECD countries, Labour Economics, 7(5): 471-505.

Blanchflower, D.G. and Meyer, B.D. (1994), A longitudinal analysis of the young selfemployed in Australia and the United States, Small Business Economics, 6(1): 1-19.

Blanchflower, D.G., Oswald, A., and Stutzer, A. (2001), Latent entrepreneurship across nations. European Economic Review, 45: 680-691.

Buttner, E.H. and. Moore, D.P (1997), Women's organizational exodus to entrepreneurship: self-reported motivations and correlates with success, Journal of Small Business Management, 35(1): 34-46.

Carter, N.M., Gartner, W.B., Shaver, K.G. and Gatewood, E.J. (2003), The career reasons of nascent entrepreneurs, Journal of Business Venturing, 18(1): 13-39.

Clark, K. and Drinkwater, S. (2000), Pushed out or pulled in? Self-employment amongt Britain's ethnic minorities, Labour Economics, 7: 603-628.

Cowling, M. and Mitchell, P. (1997), The evolution of UK self-employment: a study of government policy and the role of the macroeconomy, The Manchester School, 65(4): 427-442.

Dennis, J. (1996), Self-employment: When nothing else is available?, Journal of Labour Research, 17(4): 645-661.

Earle, J.S. and Sakova, Z. (2000), Business start-ups or disguised unemployment? Evidence on the character of self-employment from transition economies, Labour Economics, 7(5): 575-601.

Evans D.S. and Leighton, L.S. (1989), Some empirical aspects of entrepreneurship, American Economic Review, 79(3): 519-535.

Frey, B. and Benz, M. (2003), Being independent is a great thing: subjective evaluations of self-employment and hierarchy, CESifo Working Paper No. 959, Munich.

Georgellis, Y., Sessions, J.G. and Tsitsianis, N. (2005), Windfalls, wealth and the transition to self-employment, Small Business Economics, 13(2):407-428.

Gill, A.M. (1988), Choice of employment status and the wages of employees and the selfemployed: some further evidence, Journal of Applied Econometrics, 3(3): 229-234. 
Hamilton, R.T. (1989), Unemployment and business formation rates: reconciling time series and cross-section evidence, Environment and Planning, 21(2): 249-255.

Heckman, J. (1979), Sample selection bias as a specification error, Econometrica, 47(1): 153161.

Henley, A. (2004), Self-employment status: the role of state dependence and initial conditions, Small Business Economics 22(1): 67-82.

Hughes, K (2003), Pushed or pulled? Women's entry into self-employment and small business ownership, Gender, Work and Organization, 10(4): 433-454.

Hughes, K (2006), Exploring motivation and success among Canadian women entrepreneurs, Journal of Small Business and Entrepreneurship, 19(2): 107-120.

Krueger, N.F., Reilly, M.D., and Carsrud, A.L. (2000), Competing models of entrepreneurial intentions. Journal of Business Venturing 15: 411-432.

Le, A.T (1999), Empirical studies of self-employment, Journal of Economic Surveys, 13(4): 381-416.

Parker, S.C. (2004), The Economics of Self-Employment and Entrepreneurship, Cambridge (UK): Cambridge University Press.

Parker, S.C. and Johnson, P. (1996), Spatial variations in the determinants and effects of firm births and deaths, Regional Studies, 30(7): 679-688.

Rees, H. and Shah, A. (1986), An empirical analysis of self- employment in the UK, Journal of Applied Econometrics, 1(1): 95-108.

Robson, M.T. (1998), The rise in self-employment amongst UK males, Small Business Economics, 10(3); 199-212.

Sartori, A (2003), An estimator for some binary-outcome selection models without exclusion restrictions, Political Analysis, 11(2): 111-138.

Smeaton, D (2003), Self-employed workers: calling the shots or hesitant independents? A consideration of the trends, Work, Employment \& Society, 17(2): 379-391.

Storey, D.J. (1982), Entrepreneurship and the New Firm, Westport CT: Praeger Publishers.

Taylor, M (1996), Earnings, independence or unemployment: why become self-employed? Oxford Bulletin of Economics and Statistics, 58(2): 253-66.

Van Reenen, J. and Bloom, N. (2007), Measuring and explaining management practices across firms and countries, Quarterly Journal of Economics, 122 (4): 1351-1408. 
Table 1: Reported reasons for becoming self-employed - by individual

\begin{tabular}{|c|c|c|c|c|}
\hline Reason (percentage) & All & Men & Women & $\begin{array}{c}\text { t-test } \\
\text { (p-value) }\end{array}$ \\
\hline To be independent / a change & 30.2 & 32.3 & 24.9 & 0.000 \\
\hline Wanted more money & 12.7 & 14.5 & 8.0 & 0.000 \\
\hline For better conditions of working & 5.4 & 6.0 & 4.0 & 0.000 \\
\hline $\begin{array}{l}\text { Family commitments / wanted to work } \\
\text { at home }\end{array}$ & 7.7 & 2.2 & 21.5 & 0.000 \\
\hline $\begin{array}{l}\text { Opportunity arose - Capital, space, } \\
\text { equipment available }\end{array}$ & 12.5 & 12.7 & 12.1 & 0.291 \\
\hline Saw the demand / market & 8.8 & 8.8 & 8.6 & 0.722 \\
\hline Joined the family business & 6.9 & 6.6 & 7.6 & 0.025 \\
\hline Nature of the occupation & 21.5 & 21.1 & 22.5 & 0.030 \\
\hline No jobs available (locally) & 3.4 & 3.7 & 2.4 & 0.000 \\
\hline Made redundant & 9.3 & 11.6 & 3.6 & 0.000 \\
\hline Other reasons & 14.6 & 13.8 & 16.6 & 0.000 \\
\hline No reason given & 3.4 & 3.7 & 2.5 & 0.000 \\
\hline $\mathrm{N}$ & 17507 & 12582 & 4925 & \\
\hline
\end{tabular}

Source: authors’ tabulations from LFS Spring Quarters 1999-2001

Notes: Columns do not sum to 100 per cent because respondents can give up to four reasons. The right hand side reports the significance of a t-test for the difference between men and women. Bold italic indicates p-value $<0.05$ 
Table 2: Reported reasons for becoming self-employed - all responses

\begin{tabular}{|c|c|c|c|c|}
\hline Reason (percentage) & All & Men & Women & $\begin{array}{c}\text { t-test } \\
\text { (p-value) }\end{array}$ \\
\hline To be independent / a change & 22.2 & 23.6 & 18.5 & 0.000 \\
\hline Wanted more money & 9.33 & 10.6 & 6.0 & 0.000 \\
\hline For better conditions of working & 4.0 & 4.4 & 3.0 & 0.000 \\
\hline $\begin{array}{l}\text { Family commitments / wanted to work } \\
\text { at home }\end{array}$ & 5.6 & 1.6 & 16.0 & 0.000 \\
\hline $\begin{array}{l}\text { Opportunity arose - Capital, space, } \\
\text { equipment available }\end{array}$ & 9.2 & 9.3 & 9.0 & 0.520 \\
\hline Saw the demand / market & 6.4 & 6.4 & 6.4 & 0.978 \\
\hline Joined the family business & 5.0 & 4.8 & 5.6 & 0.012 \\
\hline Nature of the occupation & 15.8 & 15.4 & 16.8 & 0.009 \\
\hline No jobs available (locally) & 2.5 & 2.7 & 1.8 & 0.000 \\
\hline Made redundant & 6.8 & 8.4 & 2.7 & 0.000 \\
\hline Other reasons & 10.7 & 10.1 & 12.3 & 0.000 \\
\hline No reason given & 2.5 & 2.7 & 1.9 & 0.000 \\
\hline $\mathrm{N}$ & 23851 & 17227 & 6624 & \\
\hline
\end{tabular}

Source: authors’ tabulations from LFS Spring Quarters 1999-2001

Notes: The right hand side reports the significance of a t-test for the difference between men and women. Bold italic indicates p-value $<0.05$. 
Table 3: Factor analysis of reasons for choosing self-employment

\begin{tabular}{|c|c|c|c|c|c|c|c|}
\hline & Factor 1 & Factor 2 & Factor 3 & Factor 4 & Factor 5 & Factor 6 & Factor 7 \\
\hline Eigenvalue & 1.158 & 1.060 & 1.105 & 1.142 & 0.853 & 0.724 & 0.578 \\
\hline \multicolumn{8}{|l|}{ Factor loadings: } \\
\hline Age & 0.074 & 0.047 & -0.040 & 0.049 & -0.035 & -0.139 & -0.182 \\
\hline Female & 0.029 & 0.002 & 0.003 & 0.051 & -0.049 & 0.560 & 0.011 \\
\hline $\begin{array}{l}\text { To be independent / a } \\
\text { change }\end{array}$ & -0.175 & -0.071 & -0.210 & -0.510 & 0.813 & 0.000 & -0.000 \\
\hline Wanted more money & -0.081 & -0.021 & -0.093 & 0.187 & 0.009 & -0.147 & 0.630 \\
\hline $\begin{array}{l}\text { For better conditions of } \\
\text { working }\end{array}$ & -0.052 & -0.010 & -0.041 & -0.118 & 0.064 & -0.023 & 0.234 \\
\hline $\begin{array}{l}\text { Family commitments / } \\
\text { wanted to work at home }\end{array}$ & -0.056 & -0.048 & -0.065 & -0.091 & -0.139 & 0.558 & 0.059 \\
\hline $\begin{array}{l}\text { Opportunity arose - } \\
\text { Capital, space, } \\
\text { equipment available }\end{array}$ & -0.237 & 0.962 & 0.095 & 0.089 & 0.037 & 0.000 & 0.000 \\
\hline $\begin{array}{l}\text { Saw the demand / } \\
\text { market }\end{array}$ & -0.094 & 0.091 & -0.006 & -0.083 & 0.013 & -0.007 & 0.066 \\
\hline $\begin{array}{l}\text { Joined the family } \\
\text { business }\end{array}$ & -0.112 & -0.138 & -0.523 & 0.820 & 0.150 & -0.000 & 0.000 \\
\hline Nature of the occupation & -0.205 & -0.288 & 0.865 & 0.330 & 0.134 & -0.000 & 0.000 \\
\hline $\begin{array}{l}\text { No jobs available } \\
\text { (locally) }\end{array}$ & -0.027 & -0.029 & -0.039 & -0.069 & -0.156 & -0.043 & -0.061 \\
\hline Made redundant & -0.079 & -0.040 & -0.100 & -0.129 & -0.313 & -0.234 & -0.285 \\
\hline Other reasons & 0.991 & 0.110 & 0.050 & 0.047 & 0.035 & -0.000 & 0.000 \\
\hline
\end{tabular}

Source: authors' computations from QLFS 1999-2001

Note: maximum likelihood method ( $\log L=-240.8$ ); loadings $>0.1$ in italic; $>0.2$ in bold italic. 
Table 4: Sartori estimates of self-employment selection equation

\begin{tabular}{|c|c|c|}
\hline & $\begin{array}{l}\text { Marginal } \\
\text { Effect }\end{array}$ & p-value \\
\hline \multicolumn{3}{|l|}{ Demographic factors: } \\
\hline Age $r$ & .0041 & .000 \\
\hline Age squared/100 & -.0024 & .000 \\
\hline Female & -.0407 & .000 \\
\hline Disabled & .0058 & .000 \\
\hline Ethnic minority & .0088 & .000 \\
\hline \multicolumn{3}{|l|}{ Household and family status: } \\
\hline No. dependent Children $<16$ & .0116 & .000 \\
\hline \multicolumn{3}{|l|}{ Marital Status (reference: never married } \\
\hline Married & -.0017 & .212 \\
\hline Widowed/divorced/separated & .0007 & .670 \\
\hline \multicolumn{3}{|l|}{$\begin{array}{l}\text { Highest educational attainment } \\
\text { (reference: no qualifications): }\end{array}$} \\
\hline Degree & -.0016 & .317 \\
\hline Other higher education & -.0146 & .000 \\
\hline A-levels & .0091 & .000 \\
\hline O-levels/GCSEs & -.0103 & .000 \\
\hline Other-qualifications & -.0136 & .000 \\
\hline \multicolumn{3}{|l|}{ Housing tenure (reference: social renter): } \\
\hline Outright owner & .0437 & .000 \\
\hline Owner with mortgage & .0237 & .000 \\
\hline Private sector renter & .0333 & .000 \\
\hline \multicolumn{3}{|l|}{ Year effects (reference: 1999) } \\
\hline 2000 & -.0005 & .626 \\
\hline 2001 & -.0019 & .067 \\
\hline $\begin{array}{l}\text { Log Likelihood (combined model) } \\
\text { chi² }^{2}(28) \text { (p-value) } \\
N\end{array}$ & \multicolumn{2}{|c|}{$\begin{array}{c}147,668 \\
\text { (of which 16,860 self- } \\
\text { employed) }\end{array}$} \\
\hline
\end{tabular}

Source: authors’ computations from QLFS 1999-2001

Notes: reported equation is from the model for "to be independent / a change". Selection equations for other motivations have identical marginal effects, with only minor differences in levels of coefficient statistical significance. Model also includes 12 regional controls coefficients not reported. Full results available on request. Italic indicates p-value $<0.10$, bold italic indicates p-value $<0.05$. 
Table 5: Sartori estimates of motivation for choosing self-employment equations

\begin{tabular}{|c|c|c|c|c|c|c|c|c|c|c|}
\hline & \multicolumn{2}{|c|}{$\begin{array}{c}\text { (1) } \\
\text { Independence }\end{array}$} & \multicolumn{2}{|c|}{$\begin{array}{c}\text { (2) } \\
\text { Money }\end{array}$} & \multicolumn{2}{|c|}{$\begin{array}{c}\text { (3) } \\
\text { Working conditions }\end{array}$} & \multicolumn{2}{|c|}{$\begin{array}{c}(4) \\
\text { Family/home }\end{array}$} & \multicolumn{2}{|c|}{$\begin{array}{c}\text { (5) } \\
\text { Opportunity }\end{array}$} \\
\hline & $\begin{array}{l}\text { Marginal } \\
\text { Effect }\end{array}$ & $\begin{array}{c}\mathrm{p}- \\
\text { value }\end{array}$ & $\begin{array}{l}\text { Marginal } \\
\text { Effect }\end{array}$ & $\begin{array}{c}\text { p- } \\
\text { value }\end{array}$ & $\begin{array}{l}\text { Marginal } \\
\text { Effect }\end{array}$ & $\begin{array}{c}\mathrm{p}^{-} \\
\text {value }\end{array}$ & $\begin{array}{l}\text { Marginal } \\
\text { Effect }\end{array}$ & $\begin{array}{c}\text { p- } \\
\text { value }\end{array}$ & $\begin{array}{l}\text { Marginal } \\
\text { Effect }\end{array}$ & $\begin{array}{c}\mathrm{p}- \\
\text { value }\end{array}$ \\
\hline \multicolumn{11}{|l|}{ Demographic factors: } \\
\hline Age & .0418 & .000 & .0061 & .000 & .0044 & .000 & .0063 & .000 & .0139 & .000 \\
\hline Age squared/100 & -.0373 & .000 & -.0060 & .001 & -.0043 & .001 & -.0051 & .000 & -.0104 & .000 \\
\hline Female & -.2853 & .000 & -.1557 & .000 & -.0582 & .000 & .0824 & .000 & -.0896 & .000 \\
\hline Disabled & .0066 & .601 & .0094 & .240 & .0152 & .003 & .0090 & .034 & -.0076 & .353 \\
\hline Ethnic minority & .0933 & .000 & -.0038 & .758 & .0132 & .091 & .0033 & .626 & .0017 & .897 \\
\hline \multicolumn{11}{|l|}{ Household and family status: } \\
\hline No. dependent Children $<16$ & .0421 & .000 & .0261 & .000 & .0068 & .000 & .0311 & .000 & .0106 & .001 \\
\hline \multicolumn{11}{|l|}{ Marital Status (reference: never married } \\
\hline Married & -.0330 & .014 & .0206 & .014 & .0036 & .523 & .0241 & .000 & -.0001 & .992 \\
\hline Widowed/divorced/separated & .0170 & .311 & .0488 & .000 & .0106 & .138 & .0341 & .000 & -.0081 & .473 \\
\hline \multicolumn{11}{|l|}{$\begin{array}{l}\text { Highest educational attainment } \\
\text { (reference: no qualifications): }\end{array}$} \\
\hline Degree & .0321 & .039 & -.0231 & .023 & .0152 & .025 & -.0038 & .502 & -.0138 & .148 \\
\hline Other higher education & -.0122 & .504 & -.0330 & .006 & .0050 & .529 & -.0060 & .329 & -.0397 & .001 \\
\hline A-levels & .1077 & .000 & .0541 & .000 & .0254 & .000 & .0139 & .009 & .0091 & .290 \\
\hline O-levels/GCSEs & -.0279 & .084 & -.0276 & .006 & -.0045 & .528 & -.0044 & .382 & -.0282 & .004 \\
\hline Other-qualifications & -.0514 & .003 & -.0388 & .000 & -.0008 & .919 & -.0081 & .165 & -.0254 & .014 \\
\hline \multicolumn{11}{|l|}{ Housing tenure (reference: social renter) } \\
\hline Outright owner & .2392 & .000 & .0751 & .000 & .0371 & .000 & .0539 & .000 & .1107 & .000 \\
\hline Owner with mortgage & .1754 & .000 & .0709 & .000 & .0415 & .000 & .0384 & .000 & .0848 & .000 \\
\hline Private sector renter & .2339 & .000 & .0726 & .000 & .0453 & .000 & .0472 & .000 & .0655 & .000 \\
\hline \multicolumn{11}{|l|}{ Year effects (reference: 1999) } \\
\hline 2000 & -.0029 & .774 & -.0043 & .497 & -.0040 & .342 & -.0039 & .253 & .0026 & .688 \\
\hline 2001 & -.0342 & .001 & -.0028 & .661 & -.0050 & .247 & -.0093 & .009 & -.0058 & .380 \\
\hline $\begin{array}{l}\text { Log Likelihood (combined model) } \\
\text { chi² (29) (p-value) }_{\mathrm{N}}\end{array}$ & $\begin{array}{r}-58301 \\
0.00 \\
512\end{array}$ & & $\begin{array}{r}-54342 \\
0.00 \\
217\end{array}$ & & $\begin{array}{r}-51654 \\
0.00 \\
932\end{array}$ & & $\begin{array}{r}-51674 \\
0.00 \\
131\end{array}$ & & $\begin{array}{r}-54430 \\
0.0 \\
211\end{array}$ & \\
\hline
\end{tabular}


Table 5 (continued)

\begin{tabular}{|c|c|c|c|c|c|c|c|c|c|c|}
\hline & \multicolumn{2}{|c|}{$\begin{array}{c}(6) \\
\text { Saw the demand } \\
\end{array}$} & \multicolumn{2}{|c|}{$\begin{array}{c}\text { (7) } \\
\text { Family business } \\
\end{array}$} & \multicolumn{2}{|c|}{$\begin{array}{c}(8) \\
\text { Occupation }\end{array}$} & \multicolumn{2}{|c|}{$\begin{array}{c}(9) \\
\text { No jobs }\end{array}$} & \multicolumn{2}{|c|}{$\begin{array}{c}(10) \\
\text { Redundancy }\end{array}$} \\
\hline & $\begin{array}{l}\text { Marginal } \\
\text { Effect }\end{array}$ & $\begin{array}{c}\mathrm{p}- \\
\text { value }\end{array}$ & $\begin{array}{l}\text { Marginal } \\
\text { Effect }\end{array}$ & $\begin{array}{c}\text { p- } \\
\text { value }\end{array}$ & $\begin{array}{l}\text { Marginal } \\
\text { Effect }\end{array}$ & $\begin{array}{c}\mathrm{p}^{-} \\
\text {value }\end{array}$ & $\begin{array}{l}\text { Marginal } \\
\text { Effect }\end{array}$ & $\begin{array}{c}\text { p- } \\
\text { value }\end{array}$ & $\begin{array}{l}\text { Marginal } \\
\text { Effect }\end{array}$ & $\begin{array}{c}\mathrm{p}^{-} \\
\text {value }\end{array}$ \\
\hline \multicolumn{11}{|l|}{ Demographic factors: } \\
\hline Age & .00878 & .000 & .0021 & .014 & .0115 & .000 & .0039 & .000 & .0113 & .000 \\
\hline Age squared/100 & -.0070 & .000 & -.0004 & .630 & -.0061 & .009 & -.0031 & .000 & -.0087 & .000 \\
\hline Female & -.0627 & .000 & -.0279 & .000 & -.1544 & .000 & -.0314 & .000 & -.0883 & .000 \\
\hline Disabled & .0013 & .856 & -.0019 & .682 & .0256 & .022 & .0174 & .000 & .0042 & .271 \\
\hline Ethnic minority & .0217 & .038 & .0363 & .000 & -.0176 & .322 & .0258 & .000 & -.0247 & .002 \\
\hline \multicolumn{11}{|l|}{ Household and family status: } \\
\hline No. dependent Children $<16$ & .0103 & .000 & .0171 & .000 & .0522 & .000 & .0059 & .000 & .0026 & .113 \\
\hline \multicolumn{11}{|l|}{ Marital Status (reference: never married } \\
\hline Married & .0054 & .473 & .0003 & .951 & -.0245 & .037 & -.0127 & .001 & .0063 & .191 \\
\hline Widowed/divorced/separated & -.0033 & .738 & -.0272 & .001 & -.0268 & .081 & -.0067 & .147 & .0065 & .262 \\
\hline \multicolumn{11}{|l|}{$\begin{array}{l}\text { Highest educational attainment } \\
\text { (reference: no qualifications): }\end{array}$} \\
\hline Degree & -.0022 & .801 & -.0871 & .000 & .0742 & .000 & -.0069 & .095 & -.0041 & .398 \\
\hline Other higher education & -.0008 & .932 & -.0445 & .000 & -.0592 & .000 & -.0123 & .020 & -.0009 & .872 \\
\hline A-levels & .0226 & .003 & -.0269 & .000 & -.0023 & .856 & -.0011 & .772 & .0191 & .000 \\
\hline O-levels/GCSEs & -.0147 & .096 & -.0165 & .001 & -.0574 & .000 & -.0082 & .061 & -.0021 & .675 \\
\hline Other-qualifications & -.0052 & .563 & -.0249 & .000 & -.0364 & .013 & -.0063 & .149 & -.0132 & .015 \\
\hline \multicolumn{11}{|l|}{ Housing tenure (reference: social renter): } \\
\hline Outright owner & .0799 & .000 & .1320 & .000 & .1321 & .000 & -.0089 & .053 & .0302 & .000 \\
\hline Owner with mortgage & .0614 & .000 & .0736 & .000 & .0416 & .003 & -.0136 & .000 & .0248 & .000 \\
\hline Private sector renter & .0761 & .000 & .0743 & .000 & .1311 & .000 & -.0078 & .114 & .0023 & .791 \\
\hline \multicolumn{11}{|l|}{ Year effects (reference: 1999) } \\
\hline 2000 & .0061 & .275 & -.0042 & .267 & -.0029 & .746 & -.0188 & .000 & -.0082 & .010 \\
\hline 2001 & .0019 & .739 & -.0060 & .117 & .0035 & .702 & -.0152 & .000 & -.0149 & .000 \\
\hline $\begin{array}{l}\text { Log Likelihood (combined model) } \\
\text { chi }^{2}(28) \text { (p-value) } \\
\mathrm{N}\end{array}$ & $\begin{array}{r}-5310 \\
0.00 \\
147 \\
\end{array}$ & & $\begin{array}{r}-51918 \\
0.00 \\
114 \\
\end{array}$ & & $\begin{array}{r}-56707 \\
0.0 \\
362 \\
\end{array}$ & & $\begin{array}{r}-50504 \\
0.00 \\
57 \\
\end{array}$ & & $\begin{array}{r}-5298 \\
0.0 \\
158 \\
\end{array}$ & \\
\hline
\end{tabular}


Table 5 (continued)

\begin{tabular}{|c|c|c|}
\hline & \multicolumn{2}{|c|}{$\begin{array}{c}(11) \\
\text { Other reason }\end{array}$} \\
\hline & $\begin{array}{c}\text { Marginal } \\
\text { Effect }\end{array}$ & $\begin{array}{c}\mathrm{p}^{-} \\
\text {value }\end{array}$ \\
\hline \multicolumn{3}{|l|}{ Demographic factors: } \\
\hline Age & .0049 & .001 \\
\hline Age squared/100 & .0020 & .203 \\
\hline Female & -.0704 & .000 \\
\hline Disabled & .0441 & .000 \\
\hline Ethnic minority & .0202 & .134 \\
\hline \multicolumn{3}{|l|}{ Household and family status: } \\
\hline No. dependent Children $<16$ & .0208 & .000 \\
\hline \multicolumn{3}{|l|}{ Marital Status (reference: never married } \\
\hline Married & -.0034 & .721 \\
\hline Widowed/divorced/separated & .0071 & .540 \\
\hline \multicolumn{3}{|l|}{$\begin{array}{l}\text { Highest educational attainment } \\
\text { (reference: no qualifications): }\end{array}$} \\
\hline Degree & .0619 & .000 \\
\hline Other higher education & -.0062 & 619 \\
\hline A-levels & .0362 & .000 \\
\hline O-levels/GCSEs & -.0064 & .558 \\
\hline Other-qualifications & -.0080 & .478 \\
\hline \multirow{2}{*}{\multicolumn{3}{|c|}{$\begin{array}{l}\text { Housing tenure } \\
\text { (reference: social sector renter): }\end{array}$}} \\
\hline & & \\
\hline Outright owner & .0650 & .000 \\
\hline Owner with mortgage & .0141 & .207 \\
\hline Private sector renter & .0646 & .000 \\
\hline \multicolumn{3}{|l|}{ Year effects (reference: 1999) } \\
\hline 2000 & -.0104 & .135 \\
\hline 2001 & -.0239 & .001 \\
\hline $\begin{array}{l}\text { Log Likelihood (combined model) } \\
\text { chi }^{2}(28) \text { (p-value) } \\
\mathrm{N}\end{array}$ & \multicolumn{2}{|c|}{$\begin{array}{c}-54859.0 \\
0.000 \\
2405\end{array}$} \\
\hline
\end{tabular}

Source: authors’ computations from QLFS 1999-2001

Notes: Models also include 12 regional controls - coefficients not reported. Full results available on request. Italic indicates p-value $<0.10$, bold italic indicates p-value $<0.05$. 